\title{
Supporting Information of jp-2007-10456p
}

Solvatochromic Shift of Donor-acceptor Substituted Bithiophene in Solvents of Different Polarity: Quantum Chemical and Molecular Dynamics Simulations

\author{
Suci Meng and Jing Ma*
}

Institute of Theoretical and Computational Chemistry, Key Laboratory of Mesoscopic Chemistry of MOE, School of Chemistry and Chemical Engineering, Nanjing University, Nanjing, 210093, People's Republic of China

E-mail: majing@nju.edu.cn

\section{List of contents:}

Table S1. Selected Models in MD Simulations and Supermolecular Clusters. S3

Table S2. Optimized Geometry of $2 \mathrm{~T}$ in Vacuo and Solutions at the PCM-B3LYP/6-31G** Level. S4

Table S3. Optimized Geometry of $\mathrm{Me}_{2} \mathrm{~N}-2 \mathrm{~T}-\mathrm{NO}_{2}$ in Vacuo and Solutions at the PCM-B3LYP/6-31G** Level. .S5

Table S4. The Calculated NBO Charges of Molecular Fragments and Dipole Moments of $\mathrm{Me}_{2} \mathrm{~N}-2 \mathrm{~T}-$ $\mathrm{NO}_{2}$ in

Different Media. .S6

Table S5. Dipole Moments and Solvation Free Energies of the Ground States of $2 \mathrm{~T}$ and $\mathrm{Me}{ }_{2} \mathrm{~N}-2 \mathrm{~T}-\mathrm{NO}_{2}$ in Vacuo and Various Solutions at the PCM-B3LYP/6-31G** Level. S7 
Table S6. The TD-DFT Excitation Energies on the Basis of Explicit Solvent Models with or without Background ESP Charges and the Combined Solvation Models at the B3LYP/6-31G** Level. S8

Table S7. The HOMO-LUMO Gaps of $\mathrm{Me}_{2} \mathrm{~N}-2 \mathrm{~T}-\mathrm{NO}_{2}$ Obtained from B3LYP/6-31G** Calculations on PCM, Explicit Solvent Models, and the Combined Models in Various Media. ... S9

Figure S1. Evolution of the interaction potentials of $\mathrm{Me}_{2} \mathrm{~N}-\mathrm{T}-\mathrm{NO}_{2} \ldots \mathrm{HNHCHO}$ dimers as a function of the intermolecular distance, $r$, and the intermolecular distances obtained from the fully optimized geometries using MP2 and B3LYP methods at the 6-31G** level. $\mathrm{S} 10$

Figure S2. Radial distribution functions from the MD simulations with rigid or flexible solute in $\mathrm{CHCl}_{3}$ solutions. S11

Figure S3. Torsional potentials of $2 \mathrm{~T}$ and $\mathrm{Me}_{2} \mathrm{~N}-2 \mathrm{~T}-\mathrm{NO}_{2}$ in gas phase and in various solutions $\mathrm{S} 12$

Figure S4. Radial distribution functions and probability distributions of $\mathrm{O} \ldots \mathrm{H}-\mathrm{C}$ angles of $\mathrm{Me}_{2} \mathrm{~N}-2 \mathrm{~T}-$ $\mathrm{NO}_{2}$ in DMSO within the first solvation shell. $\mathrm{S} 13$

Figure S5. Evolution of the lowest dipole-allowed excitation energies of $\mathrm{Me}_{2} \mathrm{~N}-2 \mathrm{~T}-\mathrm{NO}_{2}$-solvents clusters as a function of the simulation time in various solutions. S14

Figure S6. The optimized structures of trimers at B3LYP/6-31G** and MP2/6-31G** level and clusters with different size at the B3LYP/6-31G** level. S16 
Table S1. Selected Models in MD Simulations and Supermolecular Clusters.

\begin{tabular}{ccccc}
\hline & \multicolumn{2}{c}{ MD simulations } & & cluster size \\
\cline { 2 - 3 } & number of solvents & & cell parameters \\
& $(a=b=c, \AA)$ & & No. of explicit solvents \\
\hline $\mathrm{CCl}_{4}$ & 102 & 25.51 & 5 \\
$\mathrm{CHCl}_{3}$ & 122 & 25.47 & 4 \\
$\mathrm{CH}_{2} \mathrm{Cl}_{2}$ & 153 & 25.45 & 4 \\
$\mathrm{DMSO}$ & 138 & 25.57 & 7 \\
$\mathrm{CHONH}$ & 246 & 25.54 & 20 \\
\hline
\end{tabular}

${ }^{a}$ The Number of Solvent molecules Corresponding to a Solute Molecule. The Concentration of Solution is Assumed to be $0.1 \mathrm{M}$ to Mimic a Dilute Solution. ${ }^{b}$ The Cubic Cell was Adopted in MD Simulations. 
Table S2. Optimized Geometries of 2T (Bond Length in $\AA$; Bond Angle and Dihedral Angel in Degree) in Gas Phase ( $\varepsilon=1.00), \mathrm{CCl}_{4}(\varepsilon=2.23), \mathrm{CHCl}_{3}(\varepsilon=4.90), \mathrm{CH}_{2} \mathrm{Cl}_{2}(\varepsilon=8.93), \mathrm{C}_{6} \mathrm{H}_{5} \mathrm{NO}_{2}(\varepsilon=34.82)$, DMSO $(\varepsilon=46.70), \mathrm{H}_{2} \mathrm{O}(\varepsilon=78.39)$, and $\mathrm{CHONH}_{2}(\varepsilon=111.00)$. The Optimizations were Performed using PCM Method at the B3LYP/6-31G** Level.

\begin{tabular}{|c|c|c|c|c|c|c|c|c|}
\hline & \multirow[b]{2}{*}{$\operatorname{Gas}^{a}(\text { expt. })^{b}$} & \multicolumn{6}{|c|}{$\left.\left.\right|_{5} ^{4}\right|_{\text {solvents }} ^{3}$} & \multirow[b]{2}{*}{$\mathrm{CHONH}_{2}$} \\
\hline & & $\mathrm{CCl}_{4}$ & $\mathrm{CHCl}_{3}$ & $\mathrm{CH}_{2} \mathrm{Cl}_{2}$ & $\mathrm{C}_{6} \mathrm{H}_{5} \mathrm{NO}_{2}$ & DMSO & $\mathrm{H}_{2} \mathrm{O}$ & \\
\hline C2-C3 & $1.378(1.370)$ & 1.378 & 1.378 & 1.378 & 1.378 & 1.378 & 1.378 & 1.378 \\
\hline $\mathrm{C} 3-\mathrm{C} 4$ & $1.424(1.452)$ & 1.425 & 1.425 & 1.425 & 1.426 & 1.426 & 1.426 & 1.426 \\
\hline C4-C5 & $1.367(1.363)$ & 1.367 & 1.367 & 1.367 & 1.368 & 1.367 & 1.368 & 1.368 \\
\hline $\mathrm{C} 2-\mathrm{C} 7$ & $1.451(1.456)$ & 1.451 & 1.451 & 1.451 & 1.452 & 1.452 & 1.452 & 1.452 \\
\hline $\mathrm{C} 7-\mathrm{C} 2-\mathrm{C} 3$ & $129.1(126.3)$ & 129.1 & 129.2 & 129.2 & 129.2 & 129.2 & 129.2 & 129.2 \\
\hline $\mathrm{S} 1-\mathrm{C} 2-\mathrm{C} 3$ & $110.1(111.8)$ & 110.1 & 110.1 & 110.0 & 110.0 & 110.0 & 110.0 & 110.0 \\
\hline $\mathrm{C} 2-\mathrm{C} 3-\mathrm{C} 4$ & $113.6(111.9)$ & 113.6 & 113.6 & 113.6 & 113.6 & 113.6 & 113.6 & 113.6 \\
\hline C3-C4-C5 & $112.9(112.3)$ & 112.9 & 113.0 & 113.0 & 113.0 & 113.0 & 113.0 & 113.0 \\
\hline C4-C5-S1 & $111.6(112.3)$ & 111.6 & 111.5 & 111.5 & 111.5 & 111.5 & 111.5 & 111.5 \\
\hline $\mathrm{C} 5-\mathrm{S} 1-\mathrm{C} 2$ & $91.8(91.7)$ & 91.8 & 91.8 & 91.8 & 91.8 & 91.8 & 91.8 & 91.8 \\
\hline$\theta_{(\mathrm{S} 1-\mathrm{C} 2-\mathrm{C} 7-\mathrm{S} 6)}$ & $157.6(148.4)$ & 158.4 & 159.4 & 159.7 & 160.1 & 160.2 & 160.2 & 160.6 \\
\hline
\end{tabular}

$a$ The B3LYP/6-31G** geometry of $2 \mathrm{~T}$ was reported in ref $19 .{ }^{b}$ Gas phase electron diffraction from ref 73. 
Table S3. Optimized Geometries of $\mathrm{Me}_{2} \mathrm{~N}-2 \mathrm{~T}-\mathrm{NO}_{2}$ (Bond Length in $\AA$; Bond Angle and Dihedral Angel in Degree) in Gas Phase $(\varepsilon=1.00), \mathrm{CCl}_{4}(\varepsilon=2.23), \mathrm{CHCl}_{3}(\varepsilon=4.90), \mathrm{CH}_{2} \mathrm{Cl}_{2}(\varepsilon=8.93), \mathrm{C}_{6} \mathrm{H}_{5} \mathrm{NO}_{2}(\varepsilon$ $=34.82)$, DMSO $(\varepsilon=46.70), \mathrm{H}_{2} \mathrm{O}(\varepsilon=78.39)$, and $\mathrm{CHONH}_{2}(\varepsilon=111.00)$. The Optimizations were Performed using PCM Method at the B3LYP/6-31G** Level.

\begin{tabular}{|c|c|c|c|c|c|c|c|c|}
\hline & \multirow[b]{2}{*}{$\operatorname{Gas}^{a}$} & \multicolumn{3}{|c|}{$\begin{array}{c}12 \\
\mathrm{H}_{3} \mathrm{C}^{1} \\
\mathrm{H}_{3} \mathrm{C}^{\prime} \\
13\end{array}$} & \multicolumn{2}{|r|}{ 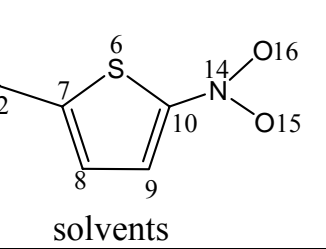 } & \multirow[b]{2}{*}{$\mathrm{H}_{2} \mathrm{O}$} & \multirow[b]{2}{*}{$\mathrm{CHONH}_{2}$} \\
\hline & & $\mathrm{CCl}_{4}{ }^{a}$ & $\mathrm{CHCl}_{3}$ & $\mathrm{CH}_{2} \mathrm{Cl}_{2}{ }^{a}$ & $\mathrm{C}_{6} \mathrm{H}_{5} \mathrm{NO}_{2}$ & $\mathrm{DMSO}^{a}$ & & \\
\hline C2-C3 & 1.379 & 1.383 & 1.386 & 1.387 & 1.389 & 1.389 & 1.389 & 1.389 \\
\hline $\mathrm{C} 3-\mathrm{C} 4$ & 1.412 & 1.408 & 1.405 & 1.403 & 1.401 & 1.401 & 1.401 & 1.401 \\
\hline C4-C5 & 1.388 & 1.392 & 1.395 & 1.397 & 1.400 & 1.400 & 1.400 & 1.400 \\
\hline $\mathrm{C} 2-\mathrm{C} 7$ & 1.435 & 1.431 & 1.427 & 1.425 & 1.422 & 1.422 & 1.422 & 1.422 \\
\hline C7-C8 & 1.393 & 1.396 & 1.399 & 1.400 & 1.403 & 1.403 & 1.403 & 1.403 \\
\hline C8-C9 & 1.408 & 1.405 & 1.402 & 1.401 & 1.399 & 1.399 & 1.399 & 1.399 \\
\hline C9-C10 & 1.374 & 1.377 & 1.380 & 1.381 & 1.383 & 1.383 & 1.383 & 1.389 \\
\hline C5-N11 & 1.371 & 1.364 & 1.359 & 1.356 & 1.353 & 1.353 & 1.353 & 1.353 \\
\hline N11-C12 & 1.456 & 1.459 & 1.460 & 1.461 & 1.463 & 1.463 & 1.463 & 1.463 \\
\hline N11-C13 & 1.456 & 1.457 & 1.458 & 1.459 & 1.460 & 1.460 & 1.460 & 1.460 \\
\hline C10-N14 & 1.421 & 1.412 & 1.406 & 1.402 & 1.398 & 1.398 & 1.398 & 1.398 \\
\hline N14-O15 & 1.237 & 1.240 & 1.243 & 1.245 & 1.247 & 1.247 & 1.247 & 1.247 \\
\hline N14-O16 & 1.240 & 1.244 & 1.247 & 1.249 & 1.251 & 1.251 & 1.251 & 1.251 \\
\hline C12-N11-C13 & 117.7 & 118.3 & 118.6 & 119.0 & 119.1 & 119.1 & 119.1 & 119.1 \\
\hline$\theta_{(\mathrm{S} 1-\mathrm{C} 2-\mathrm{C} 7-\mathrm{S} 6)}$ & 175.9 & 178.2 & 178.5 & 178.7 & 179.0 & 179.0 & 179.0 & 179.1 \\
\hline
\end{tabular}

${ }^{a}$ The B3LYP/6-31G** geometry of $\mathrm{Me}_{2} \mathrm{~N}-2 \mathrm{~T}-\mathrm{NO}_{2}$ was also reported in gas phase, $\mathrm{CCl}_{4}, \mathrm{CH}_{2} \mathrm{Cl}_{2}$, and DMSO in ref 19 by Ortí et al. 
Table S4. The Calculated NBO Charges (in e) of Molecular Fragments and Dipole Moments, $\mu$ (in Debye) of $\mathrm{Me}_{2} \mathrm{~N}-2 \mathrm{~T}-\mathrm{NO}_{2}$ in Different Media ${ }^{a}$

\begin{tabular}{|c|c|c|c|c|c|}
\hline & \multicolumn{5}{|c|}{ dipole moment, $\mu$} \\
\hline & \multicolumn{4}{|c|}{$\begin{array}{c}\mathrm{T}_{\mathrm{Me} 2 \mathrm{~N}} \\
\text { fragment charge }\end{array}$} & \multirow[t]{2}{*}{$\mu$} \\
\hline & $\mathrm{Me}_{2} \mathrm{~N}$ & $\mathrm{~T}_{\mathrm{Me} 2 \mathrm{~N}}^{b}$ & $\mathrm{~T}_{\mathrm{NO} 2}{ }^{b}$ & $\mathrm{NO}_{2}$ & \\
\hline Gas (1.00) & $-0.01(0.01)^{c}$ & $0.12(0.12)^{c}$ & $0.25(0.20)^{c}$ & $-0.36(-0.33)^{c}$ & 10.5 \\
\hline $\mathrm{CCl}_{4}(2.23)$ & $0.02(0.04)^{c}$ & $0.14(0.13)^{c}$ & $0.26(0.20)^{c}$ & $-0.42(-0.37)^{c}$ & $12.9(12.5)^{c}$ \\
\hline $\mathrm{CHCl}_{3}(4.90)$ & 0.05 & 0.15 & 0.26 & -0.46 & 14.6 \\
\hline $\mathrm{CH}_{2} \mathrm{Cl}_{2}(8.93)$ & $0.06(0.06)^{c}$ & $0.16(0.15)^{c}$ & $0.26(0.21)^{c}$ & $-0.49(-0.43)^{c}$ & $15.6(14.7)^{c}$ \\
\hline $\mathrm{C}_{6} \mathrm{H}_{5} \mathrm{NO}_{2}(34.82)$ & 0.08 & 0.17 & 0.26 & -0.52 & 16.7 \\
\hline DMSO (46.70) & $0.08(0.08)^{c}$ & $0.17(0.16)^{c}$ & $0.26(0.21)^{c}$ & $-0.52(-0.45)^{c}$ & $16.8(15.4)^{c}$ \\
\hline $\mathrm{H}_{2} \mathrm{O}(78.39)$ & 0.08 & 0.17 & 0.26 & -0.52 & 16.8 \\
\hline $\mathrm{CHONH}_{2}(111.00)$ & 0.08 & 0.19 & 0.25 & -0.52 & 16.9 \\
\hline
\end{tabular}

${ }^{a} \mathrm{NBO}$ charges were obtained from B3LYP/6-311+G**//B3LYP/6-31G** calculations and the dipole moments were calculated at B3LYP/6-31G** level. ${ }^{b} \mathrm{~T}_{\mathrm{Me} 2 \mathrm{~N}}$ and $\mathrm{T}_{\mathrm{NO} 2}$ denote the thienyl rings attached to the $\mathrm{Me}_{2} \mathrm{~N}$ and $\mathrm{NO}_{2}$ groups, respectively. ${ }^{c}$ The data in brackets come from ref 19 calculated at the $\mathrm{B} 3 \mathrm{LYP} / 6-31 \mathrm{G}^{* *}$ level. 
Table S5. Dipole Moments (Debye) and Solvation Free Energies (kcal/mol) of the Ground States of 2T and $\mathrm{Me}_{2} \mathrm{~N}-2 \mathrm{~T}-\mathrm{NO}_{2}$ in the Gas Phase and Various Solutions ${ }^{a}$

\begin{tabular}{|c|c|c|c|c|}
\hline \multirow[b]{2}{*}{ Media } & \multicolumn{2}{|c|}{ Dipole moments (D) } & \multicolumn{2}{|c|}{$\Delta G_{\mathrm{sol}}(\mathrm{kcal} / \mathrm{mol})$} \\
\hline & $2 \mathrm{~T}$ & $\mathrm{Me}_{2} \mathrm{~N}-2 \mathrm{~T}-\mathrm{NO}_{2}$ & $2 \mathrm{~T}$ & $\mathrm{Me}_{2} \mathrm{~N}-2 \mathrm{~T}-\mathrm{NO}_{2}$ \\
\hline Gas (1.00) & 0.3 & 10.5 & & \\
\hline $\mathrm{CCl}_{4}(2.23)$ & 0.3 & $12.9(12.5)^{b}$ & -0.38 & -0.83 \\
\hline $\mathrm{CHCl}_{3}(4.90)$ & 0.3 & 14.6 & -1.61 & -4.02 \\
\hline $\mathrm{CH}_{2} \mathrm{Cl}_{2}(8.93)$ & 0.3 & $15.6(14.7)^{b}$ & -2.22 & -5.61 \\
\hline $\mathrm{C}_{6} \mathrm{H}_{5} \mathrm{NO}_{2}(34.82)$ & 0.3 & 16.7 & -2.87 & -7.37 \\
\hline DMSO (46.70) & 0.3 & $16.8(15.4)^{b}$ & -2.94 & -7.51 \\
\hline $\mathrm{H}_{2} \mathrm{O}(78.39)$ & 0.3 & 16.8 & -3.01 & -7.68 \\
\hline $\mathrm{CHONH}_{2}(111.00)$ & 0.3 & 16.9 & -3.05 & -7.77 \\
\hline
\end{tabular}


Table S6. The TD-DFT Excitation Energies on the basis of Explicit Solvent Models with or without Background ESP Charges and the Combined Solvation Models at the B3LYP/6-31G** Level. Two Different Configurations were Sampled to Calculate the Excitation Energies and the Oscillator Strength $(f)$.

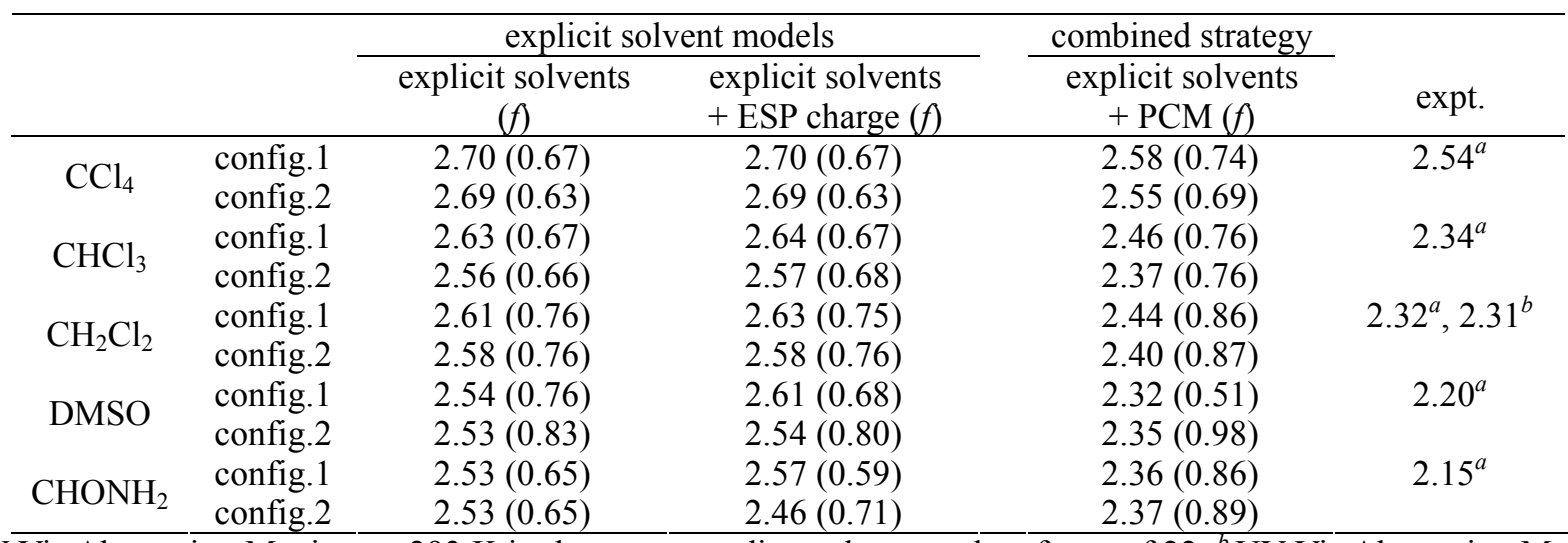

${ }^{a} \mathrm{UV}$-Vis Absorption Maxima at $293 \mathrm{~K}$ in the corresponding solvents, taken from ref $22 .{ }^{b} \mathrm{UV}$-Vis Absorption Maxima measured in dichloromethane, taken from ref 11. 


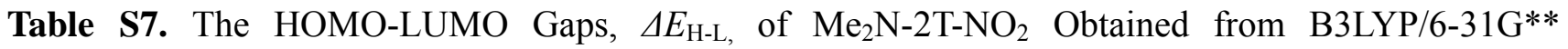
Calculations on PCM, Explicit Solvent Models, and the Combined Models in Various Media.

\begin{tabular}{|c|c|c|c|}
\hline medium $(\varepsilon)$ & PCM & explicit solvents $^{a}$ & $\begin{array}{c}\text { explicit solvents } \\
+\mathrm{PCM}^{a}\end{array}$ \\
\hline Gas (1.00) & 2.88 & & \\
\hline $\mathrm{CCl}_{4}(2.23)$ & 2.70 & 2.79 & 2.68 \\
\hline $\mathrm{CHCl}_{3}(4.90)$ & 2.59 & 2.65 & 2.49 \\
\hline $\mathrm{CH}_{2} \mathrm{Cl}_{2}(8.93)$ & 2.54 & 2.64 & 2.46 \\
\hline $\mathrm{C}_{6} \mathrm{H}_{5} \mathrm{NO}_{2}(34.82)$ & 2.49 & & \\
\hline DMSO (46.70) & 2.49 & & 2.33 \\
\hline $\mathrm{H}_{2} \mathrm{O}(78.39)$ & 2.49 & & \\
\hline $\mathrm{CHONH}_{2}(111.00)$ & 2.48 & & \\
\hline
\end{tabular}

${ }^{a}$ The average values obtained from 50 different configurations with explicit solvent molecules in the first solvation shell. 


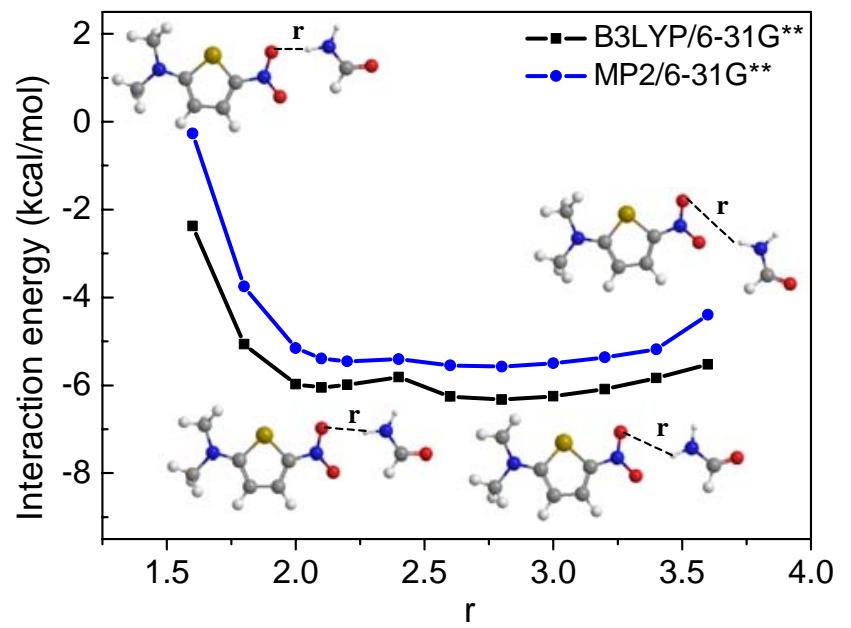

(a)

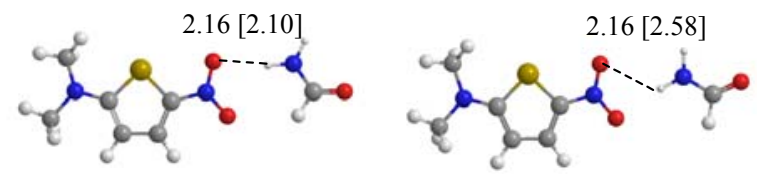

(b)

Figure S1. (a) Evolution of the interaction potentials of $\mathrm{Me}_{2} \mathrm{~N}-\mathrm{T}-\mathrm{NO}_{2} \ldots \mathrm{HNHCHO}$ dimers as a function of the intermolecular distance, $r$. The structures of the dimers are obtained by fixing O...H distance at $r$ and minimizing other variables at the MP2/6-31G** and B3LYP/6-31G** level. (b) The intermolecular distances are compared at the fully optimized geometries using MP2 and B3LYP (in brackets) methods from the restrained minima in panel a. 

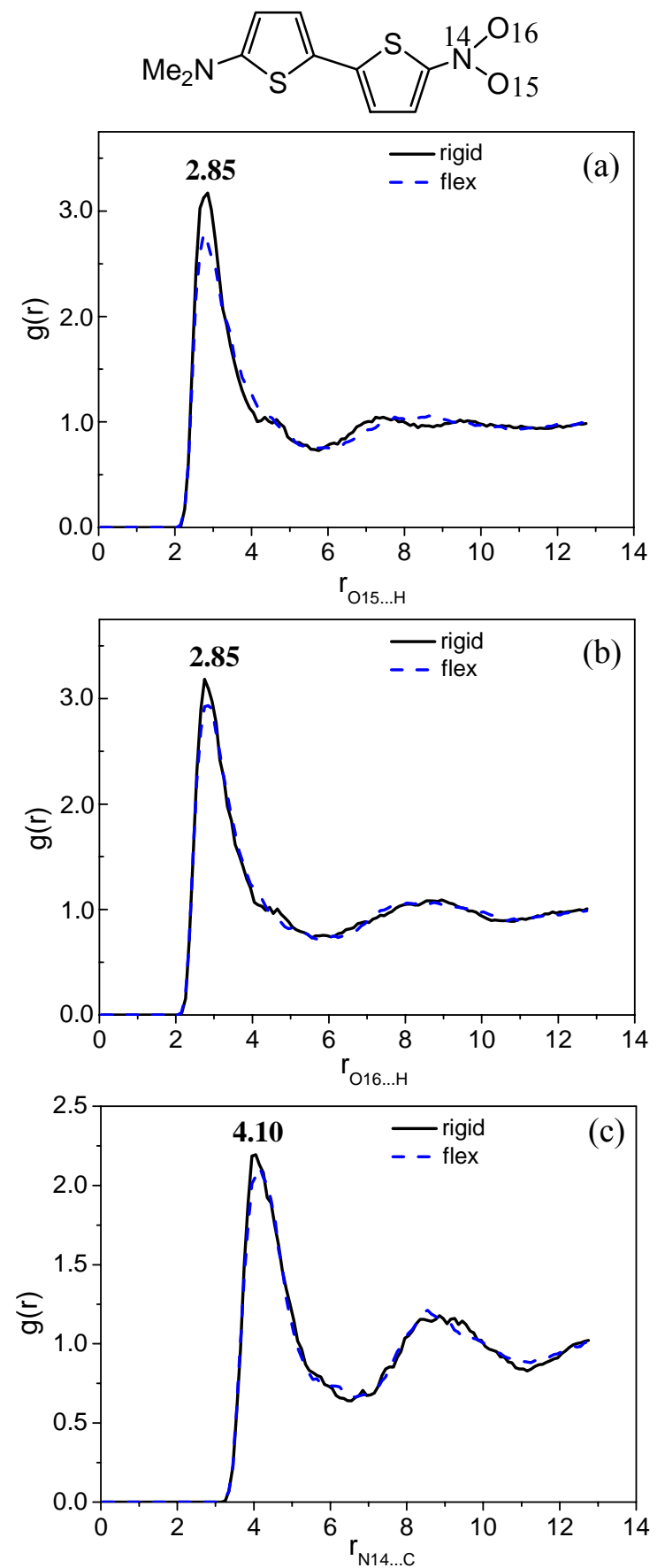

Figure S2. Radial distribution functions: (a) $g_{O 15 \ldots H}$ for oxygen $\left(\mathrm{O}_{15}\right.$ in $\left.\mathrm{Me}_{2} \mathrm{~N}-2 \mathrm{~T}-\mathrm{NO}_{2}\right)$ to hydrogen $(\mathrm{H}$ in $\left.\mathrm{CHCl}_{3}\right)$; (b) $g_{O 16 \ldots H}$ for oxygen $\left(\mathrm{O}_{16}\right.$ in $\left.\mathrm{Me}_{2} \mathrm{~N}-2 \mathrm{~T}-\mathrm{NO}_{2}\right)$ to hydrogen $\left(\mathrm{H}\right.$ in $\left.\mathrm{CHCl}_{3}\right)$; and (c) $g_{N 14 \ldots C}$ for nitrogen $\left(\mathrm{N}_{14}\right.$ in $\left.\mathrm{Me}_{2} \mathrm{~N}-2 \mathrm{~T}-\mathrm{NO}_{2}\right)$ to carbon $\left(\mathrm{C}\right.$ in $\left.\mathrm{CHCl}_{3}\right)$. They were obtained from the $\mathrm{MD}$ simulations with rigid (solid lines) and flexible (dotted lines) solute, respectively. 


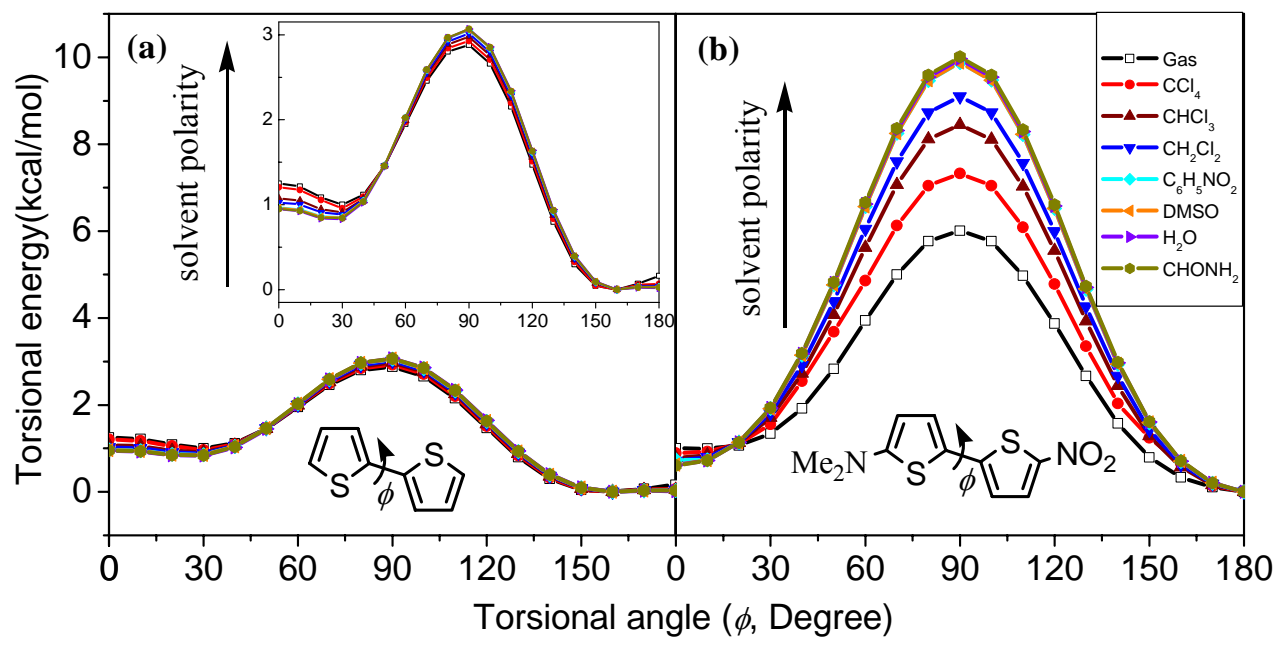

Figure S3. Torsional potentials of (a) $2 \mathrm{~T}$ and (b) $\mathrm{Me}_{2} \mathrm{~N}-2 \mathrm{~T}-\mathrm{NO}_{2}$ in gas phase and in $\mathrm{CCl}_{4}, \mathrm{CHCl}_{3}$, $\mathrm{CH}_{2} \mathrm{Cl}_{2}, \mathrm{C}_{6} \mathrm{H}_{5} \mathrm{NO}_{2}$, DMSO, $\mathrm{H}_{2} \mathrm{O}$, and $\mathrm{CHONH}_{2}$ solutions (at the level of B3LYP/6-31G**/PCM). 

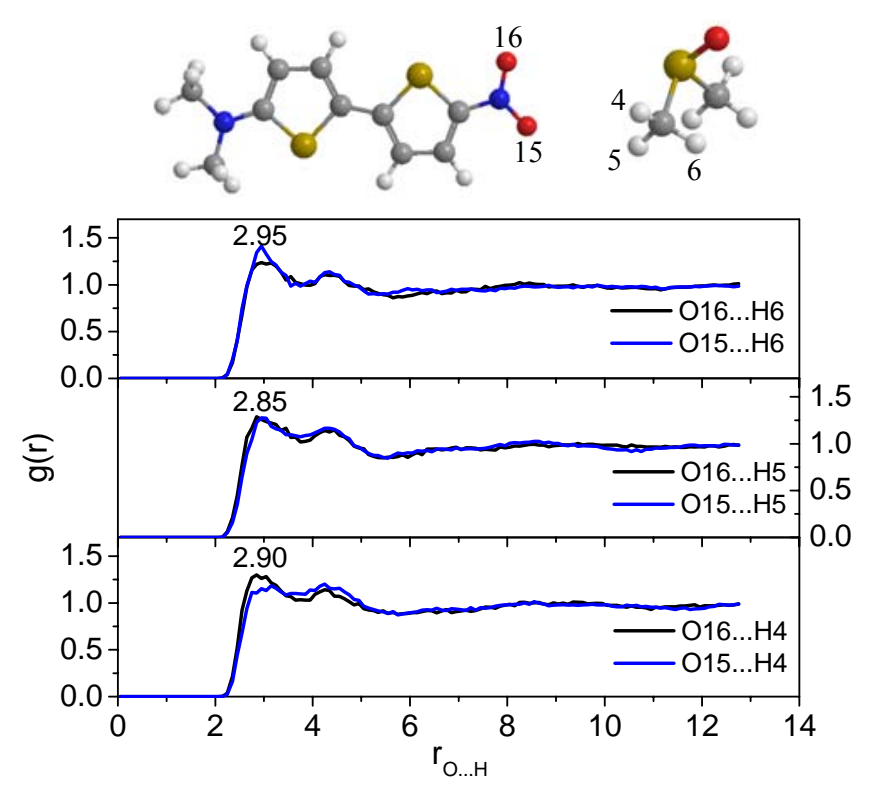

(a) RDFs

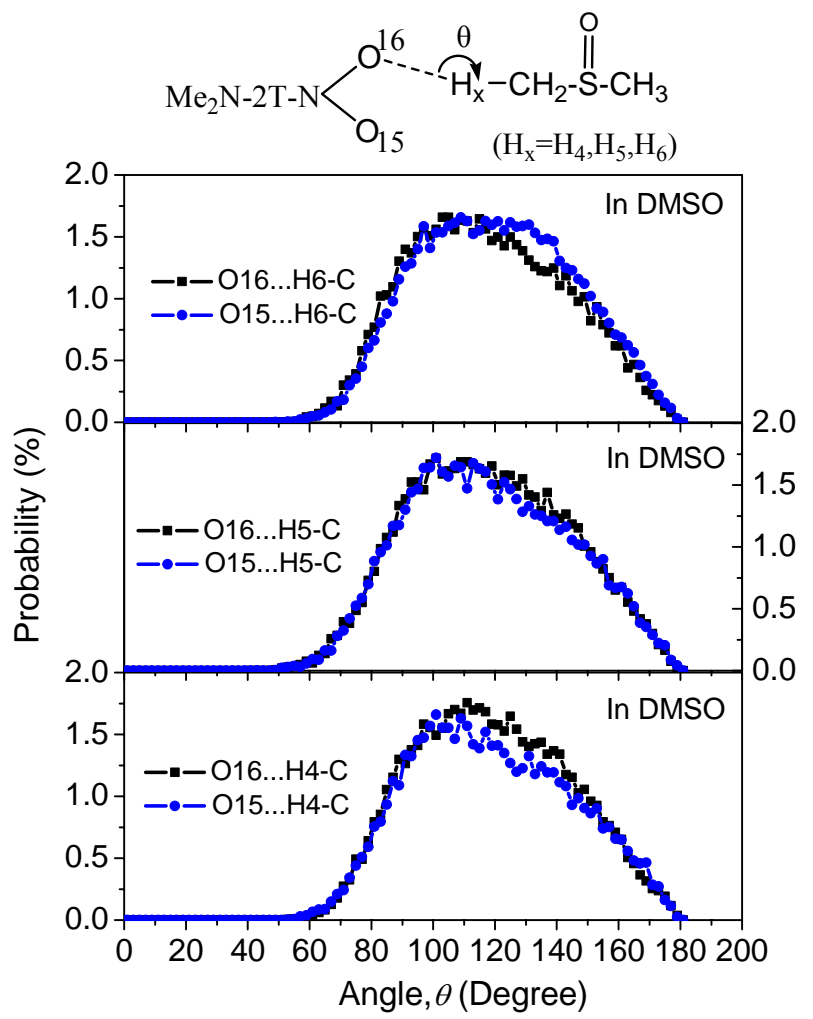

(b) Probability distributions of O...H-C angle

Figure S4. (a) Radial distribution functions, $g_{O 15 \ldots H}$ and $g_{O 16 \ldots H}$ for oxygen in $\mathrm{Me}_{2} \mathrm{~N}-2 \mathrm{~T}-\mathrm{NO}_{2}$ to hydrogen in DMSO (the statistical error is $\pm 0.05 \AA$ ); (b) probability distributions of O...H-C angles of $\mathrm{Me}_{2} \mathrm{~N}-2 \mathrm{~T}-\mathrm{NO}_{2}$ in DMSO within the first solvation shell. The data come from the statistical analysis of MD simulations in dimethyl sulfoxide solutions. 

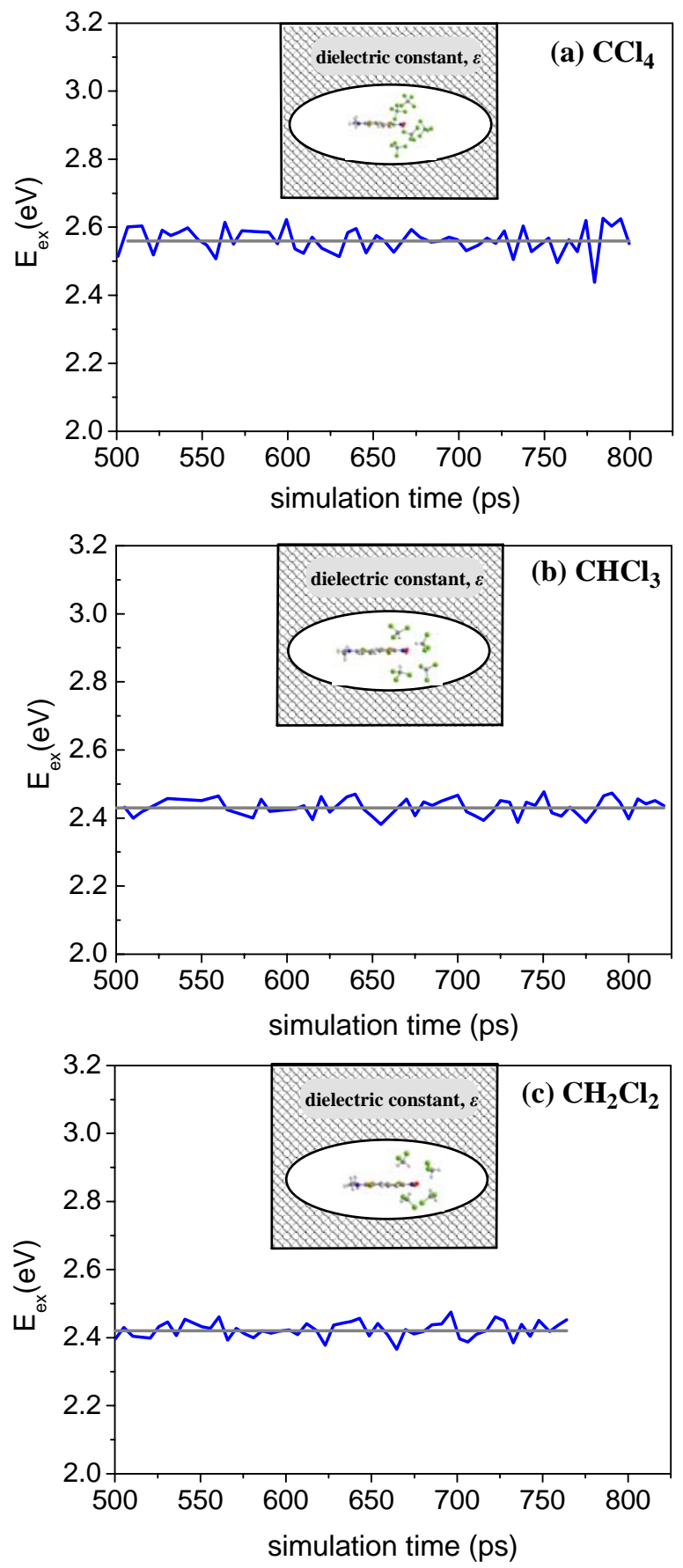

to be continued 

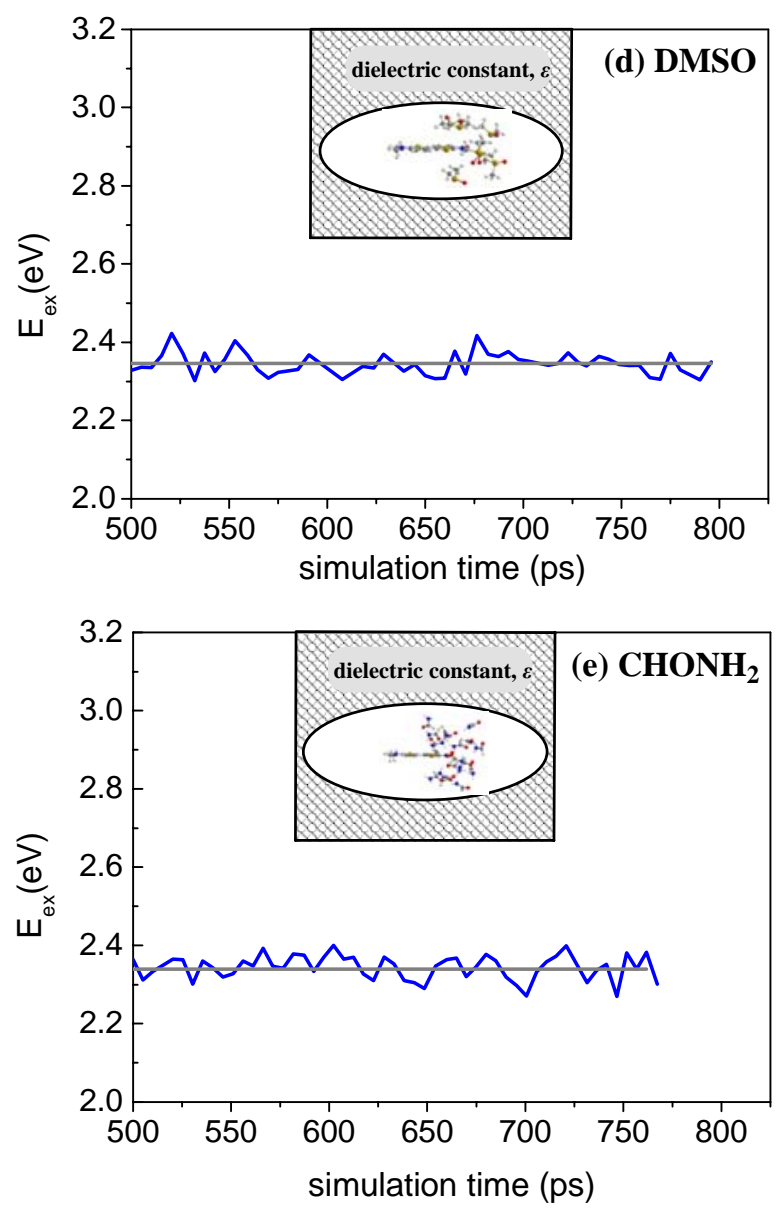

Figure S5. Evolution of the lowest dipole-allowed excitation energies of $\mathrm{Me}_{2} \mathrm{~N}-2 \mathrm{~T}-\mathrm{NO}_{2}$-solvents clusters as a function of the simulation time in (a) $\mathrm{CCl}_{4}$; (b) $\mathrm{CHCl}_{3}$; (c) $\mathrm{CH}_{2} \mathrm{Cl}_{2}$; (d) $\mathrm{DMSO}$; and (e) $\mathrm{CHONH}_{2}$ solutions. The clusters were sampled at above $5 \mathrm{ps}$ time intervals from the MD simulations. The combined discrete/continuum solvation model is employed to perform the TD-DFT/PCM calculations at the B3LYP/6-31G** level. The average values (gray lines) are obtained from a set of 50 different supermolecular clusters. 


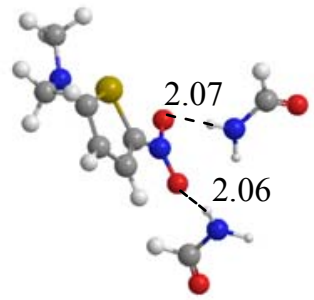

B3LYP

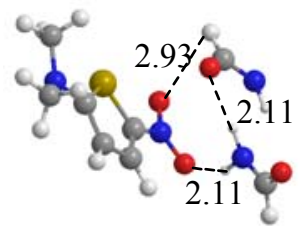

MP2

(a)

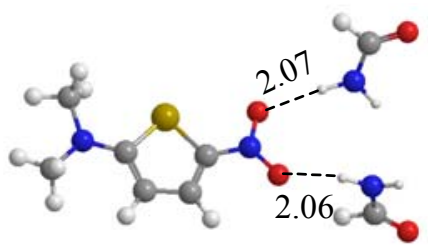

Cluster with 2 Solvents

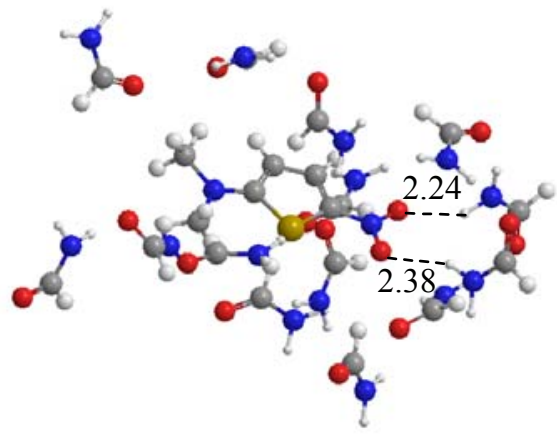

Cluster with14 Solvents

(b)

Figure S6. The optimized structures of (a) trimers at B3LYP/6-31G** and MP2/6-31G** level; and (b) clusters with 2 solvents and with 14 solvents at the B3LYP/6-31G** level. For the large cluster, the initial structure was obtained from the MD simulation, and the optimized configuration was sampled when the energy of the cluster converged to a very flat potential surface. 